\title{
Parental Counseling in Fostering Mathematics Learning of Elementary School Children in Pojok Hamlet, Campurdarat District, Tulungagung Regency
}

\section{Penyuluhan Orang Tua dalam Membimbing Belajar Matematika Anak Sekolah Dasar di Dusun Pojok Kecamatan Campurdarat}

\author{
Dewi Anggreini ${ }^{\mathrm{a}}$, Diesty Hayuhantika ${ }^{\mathrm{a}}$, \& Nanis Hairunisya ${ }^{\mathrm{b}}$ \\ ${ }^{a}$ Program Studi Pendidikan Matematika, Universitas Bhinneka PGRI, Jl. Mayor Sujadi No.7 Plosokandang Tulungagung Jawa Timur 66229, \\ Indonesia \\ ${ }^{b}$ Program Studi Pendidikan Ekonomi, Universitas Bhinneka PGRI, Jl. Mayor Sujadi No.7 Plosokandang Tulungagung Jawa Timur 66229,
} Indonesia

\begin{abstract}
Parents play an important role in education, because they can help develop children's learning potential and become a determining factor for the child's future. Children must be given the best education from an early age, so that it can have a positive impact on children when they become students at school. The purpose of this service was to determine the importance of learning mathematics, to motivate and foster children's interest in mathematics, to determine on how to help children in learning mathematics properly, to determine the practical and humanist mathematics learning knowledge, and to provide the appropriate and fun learning methods for children. In this service activity, there were several problems encountered in Pojok Hamlet, among others, parents had limited ability and time to foster children's mathematics learning, children had difficulty in understanding mathematics, parents were not confident in fostering their children to learn mathematics. The methods used in the implementation of this activity were the lecture and question and answer methods. This service activity was attended by parents of grade 2 and 3 at SDN 3 Pojok, Campurdarat District. Based on the results of questionnaires and interviews conducted in this service activity, it was found that parents were very enthusiastic and their knowledge increased after attending the counseling. There was an increase in the frequency of parents in fostering and helping their children to study at home. Referring to the results of this counseling activity, it can be concluded that parents should provide mathematical knowledge from an early age to their children, specifically for early grade children, particularly grades 1, 2, and 3. Basic mathematical knowledge can be used as a provision for skills for parents in assisting their children to learn mathematics. Parents can use mathematics teaching aids in the neighborhood in fostering their children to learn mathematics about addition, multiplication and division.
\end{abstract}

\begin{abstract}
Abstrak
Peran orangtua terhadap pendidikan sangatlah penting karena membantu perkembangan belajar anak dan menjadi salah satu faktor penentu masa depan anak. Sejak dini anak-anak harus diberikan pendidikan yang terbaik agar memberikan dampak positif bagi anak didik. Tujuan pengabdian ini adalah mengetahui pentingnya belajar ilmu matematika, memotivasi dan menumbuhkan minat anak terhadap matematika, mengetahui bagaimana cara mendampingi anak belajar matematika dengan baik, mengetahui pengetahuan belajar matematika yang praktis dan humanis dan metode belajar yang tepat dan menyenangkan bagi anak. Permasalahan yang dihadapi di dusun Pojok yaitu orang tua mempunyai keterbatasan kemampuan dan waktu dalam membimbing belajar matematika anak, anak mengalami kesulitan dalam memahami matematika, orang tua tidak percaya diri membimbing anak belajar matematika. Metode pelaksanaan kegiatan berupa ceramah dan tanya jawab. Kegiatan pengabdian ini diikuti oleh orang tua siswa kelas 2 dan 3 SDN 3 Pojok Kecamatan Campurdarat. Kegiatan pengabdian ini diperoleh beberapa hasil yaitu dari hasil angket dan wawancara, orang tua sangat antusias dan pengetahuannya bertambah setelah mengikuti penyuluhan.Terjadi peningkatan frekuensi orang tua dalam membimbing dan membantu putra-putrinya belajar di rumah. Kesimpulan dari penyuluhan ini adalah orang tua hendaknya memberikan pengetahuan matematika sejak dini bagi anak khususnya untuk anak kelas awal yaitu
\end{abstract}


kelas 1, 2, dan 3. Pengetahuan matematika dasar dapat dijadikan bekal keterampilan bagi orang tua dalam mendampingi anakanaknya belajar matematika. Orang tua bisa menggunakan alat peraga matematika yang ada di lingkungan sekitar dalam membimbing putra putrinya belajar matematika tentang penjumlahan, perkalian dan pembagian.

(C) 2020 Author(s).

Keywords: Mathematics, Learning Motivation, Learning Assistance, Parent Counseling.

\section{Pendahuluan}

Secara geografis Desa Pojok Kecamatan Campurdarat merupakan desa yang berada pada bagian selatan wilayah Kabupaten Tulungagung. Desa Pojok memiliki luas wilayah 410.830 Ha dengan jumlah penduduk sebanyak 7.310 jiwa dan mayoritas berprofesi sebagai petani dikarenakan lebih dari $60 \%$ areanya adalah pertanian dan ladang (BPS, 2020). Menurut data pada tahun 2019, jumlah penduduk di Desa Pojok sekitar 7217 jiwa terdiri dari laki-laki sekitar 3861 jiwa dan wanita sekitar 3356 jiwa. Mayoritas masyarakat Desa Pojok berprofesi sebagai petani, dan sebagian sebagai peternak, penambang pasir, dan pengrajin batu marmer. Pendidikan masyarakat mayoritas lulusan SD/SMP/SMA. Pendapatan masyarakat ditunjang dari hasil pertanian, perkebunan, peternakan, dan pengrajin. Ciri Khas sosial kemasyarakatan desa Pojok adalah gotong royong dan masyarakat yang ramah. Selain itu masyarakat desa Pojok juga secara rutin melaksanakan kegiatan yasinan dan pengajian. Kegiatan yasinan diadakan di setiap rumah masyarakat secara bergilir setiap hari kamis (malam jum'at) dan untuk kegiatan pengajian biasa dilakukan oleh masyarakat desa Pojok ketika memperingati hari-hari besar dalam agama islam.

Desa Pojok memiliki 4 Sekolah Dasar Negeri yaitu Sekolah Dasar Negeri 1, 2, 3 dan 4 Pojok. Dimana rata-rata siswa dari setiap Sekolah Dasar tersebut berkisar lebih dari 129 siswa (Kemendikbud, 2020). Banyaknya siswa dari Sekolah Dasar tersebut masih sangat memerlukan bimbingan yang ekstra dalam pembelajaran setiap harinya. Pembelajaran daring yang dilakukan pada saat ini membuat orangtua dituntut untuk menjadi guru di rumah. Orangtua harus berperan dalam dalam pembentukan karakter anak melalui pendidikan. Mayoritas orangtua di dusun Pojok mengaku bahwa mereka tidak sanggup dalam mengajari anak-anaknya matematika, disamping itu mereka juga bingung akan cara yang tepat dalam mengajarkannya. Mereka selalu beranggapan kalau ilmu matematika merupakan pelajaran yang paling sulit, hal ini menjadikan pelajaran matematika sebagai momok yang dirasakan oleh siswa ataupun orang tua (Purwanto and Kurniasih, 2018). Penelitian yang dilakukan di Inggris menyimpulkan adanya peran aktif orangtua sangat penting dalam proses pendidikan si anak Orangtua yang hanya bersikap pasif dan sekedar memberikan fasilitas saja serta tidak bersentuhan langsung dengan psikologis anak maka akan kurang memberikan dampak terhadap perkembangan pendidikan anak (Hulukati, 2015). Lingkungan keluarga dan rumah memiliki peranan yang besar dalam pembentukan perilaku anak, sehingga diperlukan tanggung jawab dan usaha yang maksimal dari orangtua terkait dalam proses pembentukan perilaku anak. (Saputro., 2018).

Peran orangtua terhadap pendidikan sangatlah penting. Sejak dini anak-anak harus diberikan pendidikan yang terbaik, dengan pendidikan yang terbaik akan memberikan dampak positif yang baik bagi anak didik. Bloom berpendapat bahwa perkembangan kepribadian, intelegensi dan tingkah laku sosial sudah berkembang pesat ketika anak masih usia dini (Agustin, Sumarmini and Prabowo, 2015). Potensi dan bakat yang dimiliki anak sangatlah diperhatikan untuk menunjang proses pembelajaran ditambah dengan dorongan dan motivasi untuk selalu tetap semangat belajar. Setiap orangtua dituntut untuk dapat melakukan stimulus tersebut dengan niat iklas demi mendapatkan generasi berakhlak dan berwawasan yang tinggi serta pantang menyerah menghadapi rintangan, (Saputro., 2018). Keberhasilan pembangunan pendidikan di era otonomi daerah tidak lepas dari peran serta masyarakat pada umumnya. Secara lebih khusus, keterlibatan orangtua akan berdampak positif bagi outcome pendidikan dasar (Hasbullah, 2005). Belajar

\footnotetext{
* Corresponding author:

E-mail address: anggreini1104@gmail.com (Dewi Anggreini)
} 
secara jarak jauh di rumah berarti para orang tua harus menjadi peran penting dalam memantau kegiatan anak-anak di rumah serta turut bertanggung jawab penuh atas kemajuan belajar anak selama pembelajaran daring di Era Covid-19. (Abidin, 2020). Peran serta orang tua untuk memberikan pengarahan, bimbingan dalam pelajaran matematika sangat diperlukan. Khususnya dalam masa pembelajaran daring dimana anak anak banyak menghabiskan waktu dirumah bersama orang tua (Subianto, 2013).

Berdasarkan hasil observasi tim pengabdian masyarakat yang telah dilakukan diperoleh fakta bahwa banyak anak usia sekolah dasar di dusun Pojok desa Pojok Kecamatan Campurdarat yang mengalami kesulitan belajar khususnya dalam pelajaran matematika. Berdasarkan hasil wawancara dengan orang tua yang memiliki anak kelas 2 dan kelas 3 , kesulitan anak dalam belajar matematika banyak dialami pada materi perkalian, pembagian, bangun ruang dan bangun datar. Orang tua banyak yang bekerja di pagi hari sehingga tidak bisa maksimal mendampingi anaknya belajar pada masa pembelajaran daring. Orang tua mengalami kesulitan dalam membimbing anak-anaknya khususnya belajar matematika. Apabila anak-anak diharuskan belajar diluar melalui bimbingan belajar, dimana tidak semua orang tua memiliki kecukupan biaya serta banyaknya orangtua yang keberatan dikarenakan mayoritas berprofesi sebagai petani. Permasalahan lain yaitu, mayoritas anak-anak menghabiskan banyak waktunya untuk bermain HP/gadget di rumah bukan untuk belajar tetapi untuk bermain game atau lainnya. Sebagian orang tua di Dusun Pojok masih jarang yang mendapatkan pelatihan tentang pendampingan matematika bagi anak sekolah dasar.

Dari beberapa penjelasan fakta di atas adalah faktor-faktor pendorong untuk melakukan kegiatan pengabdian penyuluhan bagi orang tua. Tujuan kegiatan pengabdian yang akan dilakukan adalah: memberikan informasi kepada masyarakat pentingnya mempelajari ilmu pengetahuan khususnya matematika sejak dini bagi anak, meningkatkan motivasi dan menumbuhkan minat anak terhadap matematika, memberikan informasi pendampingan belajar anak secara baik dan menyenangkan dalam pembelajaran matematika, memberikan informasi dan cara belajar matematika yang praktis dan humanis, memberikan informasi tentang metode mengajarkan matematika yang tepat dan menyenangkan. Setelah adanya pendampingan diharapkan bisa memberikan bekal bagi orang tua bisa untuk menyukai matematika sehingga bisa memberikan motivasi dan merubah mindset kepada anaknya bahwa matematika itu sulit menjadi matematika itu mudah.

\subsection{Target dari kegiatan Pengabdian Kepada Masyarakat}

Adapun target dari kegiatan pengabdian kepada masyarakat yang akan dilakukan adalah terciptanya pengetahuan dan keterampilan orang tua dalam membimbing anak dengan baik dan tepat sehingga mampu memberikan pemahaman akan konsep matematika yang baik bagi siswa, memberikan pengetahuan dan metode yang tepat dalam membimbing bagi orangtua sehingga tidak lagi mengalami kesulitan dalam mendampingi putra-putrinya belajar matematika, menciptakan kesadaran dalam diri setiap warga khususnya orangtua akan pentingnya pembelajaran di usia dini, berkembangnya potensi SDM warga yang dinamis, aktif, progresif dan inovatif.

\subsection{Sasaran kegiatan Pengabdian Kepada Masyarakat}

Kegiatan pengabdian kepada masyarakat yang akan dilakukan adalah menitikberatkan pada pemberdayaan potensi masyarakat di desa Pojok, Kecamatan Campurdarat sehingga sasarannya adalah Para orangtua yang memiliki anak di usia Sekolah Dasar kelas 2 dan kelas 3.

\section{Metode Pelaksanaan}

\subsection{Metode Pendekatan}

Metode yang digunakan dalam pelaksanaan kegiatan ini berupa penyuluhan dan tanya jawab. Kegiatan pengabdian menggunakan metode ceramah oleh ketua tim pengabdian dan anggota Tim Pengabdian. Pelaksanaan secara teknis di lapangan melibatkan beberapa mahasiswa dari Universitas Bhinneka PGRI. Tim pengabdian berperan sebagai 
narasumber dalam kegiatan dan disertai dengan tanya jawab oleh peserta penyuluhan. Metode yang digunakan dalam pelaksanaan kegiatan ini adalah sebagai berikut:

\section{a) Metode Ceramah}

Metode ceramah oleh tiga narasumber dosen dari Universitas Bhinneka PGRI, dengan alokasi waktu masing masing narasumber adalah 30 menit. Metode ceramah untuk memberikan penyuluhan tentang mengetahui pentingnya belajar ilmu matematika bagi anak, memotivasi dan menumbuhkan minat anak terhadap matematika, mengetahui bagaimana cara mendampingi anak belajar matematika dengan baik, aplikasi matematika dalam kehidupan sehari hari, mengetahui tentang pengetahuan belajar matematika yang praktis dan humanis, materi bangun ruang dan bangun datar. Selanjutnya dilanjutkan penyuluhan tentang materi perkalian dan pembagian pada materi kelas dua dan kelas tiga sekolah dasar. Sesi penyuluhan terakhir yaitu tentang metode mengajarkan matematika yang tepat dan menyenangkan pada anak.

\section{b) Metode Tanya Jawab}

Metode tanya jawab seputar masalah ataupun kesulitan orang tua siswa dalam mendampingi belajar anak di rumah. Metode tanya jawab dengan alokasi waktu tanya jawab setiap pemateri adalah satu jam. Dalam melaksanakan penyuluhan ini dibutuhkan beberapa langkah mulai dari persiapan hingga evaluasi kegiatan. Adapun berbagai bentuk kegiatan yang akan dilaksanakan adalah sebagai berikut. Persiapan kegiatan yang dilaksanakan oleh Tim PKM untuk merencanakan kegiatan pelatihan yang mencakup waktu, materi, dan teknis pelaksanaan kegiatan. Persiapan kegiatan juga dilakukan gladi bersih satu hari sebelum pelaksanaan kegiatan pengabdian masyarakat yaitu pada tanggal 23 Oktober 2020 bertempat di balai desa dusun Pojok untuk memastikan sarana dan prasarana dan sudah tersiapkan dengan baik atau belum, dan juga mencegah kendala teknis yang kemungkinan akan terjadi pada saat akan dilakukan penyuluhan pada tanggal 24 Oktober 2020.

Pelaksanaan penyuluhan tentang pentingnya belajar ilmu matematika bagi anak, memotivasi dan menumbuhkan minat anak terhadap matematika, mengetahui bagaimana cara mendampingi anak belajar matematika dengan baik dan menyenangkan, mengetahui tentang pengetahuan belajar matematika yang praktis dan humanis, penyuluhan matematika materi perkalian dan pembagian pada materi siswa sekolah dasar kelas 2 dan kelas 3. Selanjutnya, penyuluhan tentang metode mengajar yang tepat dan menyenangkan untuk anak sekolah dasar. Evaluasi kegiatan secara umum oleh peserta PKM serta Tim PKM hingga selesainya laporan kegiatan. Dalam pelatihan ini didukung oleh 3 narasumber atau pemateri yaitu ibu Dewi Anggreini, S.Si., M.Sc. sebagai pembicara pertama, ibu Diesty Hayuhantika, M.Pd sebagai pembicara kedua dan ibu Dr. Nanis Hairunisya, MM. Sebagai pembicara ketiga, yang akan memberikan materi penyuluhan di Dusun Pojok Kecamatan Campurdarat.

Pada kegiatan pertama peserta pelatihan akan menerima materi yang disampaikan oleh pemateri pertama yaitu pentingnya mempelajari ilmu pengetahuan khususnya matematika sejak dini bagi anak, mengapa perlu belajar matematika, dan memotivasi serta menumbuhkan minat anak terhadap matematika, aplikasi matematika dalam kehidupan sehari-hari, penguatan materi geometri bagi orang tua dalam mendampingi anak belajar. Kemudian pada tahap kedua peserta akan mendapatkan materi dari pemateri kedua yaitu materi perkalian dan pembagian beserta contoh-contoh mengerjakan soal perkalian dan pembagian menggunakan alat peraga yang diperoleh di lingkungan sekitar. Selanjutnya pemateri ketiga menyampaikan materi tentang metode pembelajaran yang tepat dan menyenangkan pada anak. Kegiatan PKM ini berupa penyuluhan dilaksanakan di Ruang Pertemuan Balai Desa Dusun Pojok Kecamatan Campurdarat Kabupaten Tulungagung. Peserta kegiatan PKM ini adalah Masyarakat atau orangtua yang memiliki anak usia Sekolah Dasar yaitu kelas 2 dan kelas 3 yang bersekolah di SDN 3 Pojok. Pelaksanaan kegiatan pengabdian ini dilaksanakan pada hari sabtu, tanggal 24 Oktober 2020 dan pendampingan hingga beberapa bulan kedepan. 


\subsection{Peran dari Tim Mitra}

Peran dari tim mitra (SDN 3 Pojok) adalah berperan mendampingi ketika membentuk komunitas kegiatan seperti halnya: (a) Membantu memberikan masukan tentang kesulitan-kesulitan apa saja yang dialami siswa dalam belajar matematika yang sesuai dengan jenjang kelas di Sekolah Dasar; (b). Memberikan data data orang tua siswa yaitu orang tua siswa kelas 2 dan kelas 3 sebagai target penyuluhan pengabdian; (c) sebagai penghubung untuk berkomunikasi antara tim pengabdian masyarakat dengan para orang tua wali murid kelas 2 dan kelas 3 sekolah dasar terkait rencana pelaksanaan kegiatan pengabdian. Partisipasi mitra pada kegiatan Pengabdian kepada Masyarakat dalam keterlibatan aktif mitra sejak pembentukan hingga selesainya pelaksanaan kegiatan komunitas belajar untuk tujuan bersama.



Fig. 1. Diagram Alir Pelaksanaan Kegiatan

\section{Hasil dan Pembahasan}

Pelaksanaan Kegiatan pengabdian ini berupa pendampingan bagi orang tua siswa tentang bagaimana mendampingi anak belajar matematika yang baik dan menyenangkan serta untuk meningkatkan motivasi belajar siswa di Dusun Pojok Kecamatan Campurdarat Kabupaten Tulungagung. Pelaksanaan pengabdian ini melalui beberapa tahapan, antara lain:

\subsection{Persiapan}

Tahap persiapan juga dibagi menjadi 5 kegiatan, yakni :

\subsubsection{Observasi dan Wawancara}

Pada tahap ini melakukan observasi pada lokasi sasaran untuk mengetahui beberapa permasalahan yang terjadi dilapangan sebenarnya, dengan begitu target atau tujuan diadakan pengabdian ini bisa tepat sasaran. Observasi 
dilaksanakan bersama tim PKM pada Tanggal 7 Oktober 2020 di dusun Pojok kecamatan Campurdarat. Beberapa lokasi yang diobservasi adalah SDN 3 Pojok dan balai desa pojok yang dijadikan tempat penyuluhan. Pada saat observasi tim pengabdian bertemu dengan perwakilan orang tua siswa kelas 2 dan kelas 3, bapak kepala desa yaitu bapak Bondan Wiratmoko, S.H. beserta ibu penggerak PKK yaitu ibu Ismiyati di balai desa dusun Pojok kecamatan Campurdarat. Berdasarkan Hasil wawancara dengan perwakilan orang tua, ibu penggerak PKK dan Bapak Kepala Desa diperoleh bahwa kesulitan orang tua terkait pembelajaran matematika khususnya materi matematika yaitu pada perkalian dan pembagian serta materi bangun ruang dan bangun datar. Para orang tua juga mengalami kesulitan dalam mendampingi anaknya selama pembelajaran daring di rumah.

\subsubsection{Pembuatan Proposal}

Setelah melakukan observasi ke lokasi pengabdian, tim pengabdian menyusun proposal untuk menuliskan dan mendeskripsikan permasalahan yang ditemukan di wilayah dusun Pojok serta mengatasi beberapa permasalahan tersebut.

\subsubsection{Pemberian angket bagi orang tua siswa}

Setelah pembuatan proposal pengabdian maka tim pengabdian menyusun angket yang berisi sepuluh pertanyaan soal uraian. Tujuan pemberian angket adalah untuk mengetahui kesulitan orang tua dalam mendampingi anak-anaknya belajar di rumah selama pembelajaran daring serta sebagai bahan pembuatan materi penyuluhan pengabdian. Selain itu tujuan diberikan angket adalah untuk memperkuat hasil observasi dan wawancara yang telah dilakukan sebelumnya sehingga materi penyuluhan dapat tepat sesuai dengan permasalahan yang dialami orang tua siswa. Angket berisi sepuluh pertanyaan soal uraian yang bisa dikerjakan langsung dibawah soal yang diajukan. Pada bagian akhir pertanyaan angket orang tua diberi pertanyaan bagaimana harapan orang tua kedepan untuk pembelajaran yang saat ini sedang berlangsung. Hasil angket menunjukkan bahwa rata-rata kesulitan orang tua selama pembelajaran daring adalah pada pembelajaran matematika khususnya materi tentang perkalian dan pembagian serta bangun ruang dan bangun datar.

\subsubsection{Pengurusan Perijinan}

Setelah melakukan penyusunan proposal berdasarkan permasalahan yang terjadi di lapangan, tim melakukan pengurusan perijinan untuk mendapatkan persetujuan pelaksanaan pengabdian ini ke Kepala Desa Pojok Kecamatan Campurdarat serta bertemu dengan beberapa perangkat desa dan ketua penggerak PKK untuk memantapkan kegiatan yang akan dilakukan.

\subsubsection{Pembuatan materi penyuluhan}

Kegiatan ini dilanjutkan dengan pembuatan materi penyuluhan yang akan diberikan kepada orang tua siswa. Materi penyuluhan akan ditampilkan dengan bentuk ppt menggunakan proyektor yang sudah disediakan oleh bagian operator dusun pojok. Materi penyuluhan berisi solusi dari permasalahan yang diperoleh dari hasil observasi, wawancara dan pengisian angket yang telah diisi oleh orang tua siswa. Materi penyuluhan dilengkapi dengan contoh soal-soal materi perkalian pembagian beserta bangun ruang dan bangun datar dalam kehidupan sehari-hari. Sebelum dilaksanakan kegiatan pengabdian masyarakat juga dilaksanakan persiapan yaitu acara gladi bersih untuk menanggulangi jika ada kendala di lapangan. Gladi bersih dilaksanakan pada hari Jumat, tanggal 23 Oktober 2020.

\subsection{Pelaksanaan Kegiatan}

Pelaksanaan Kegiatan Penyuluhan pendampingan belajar anak pada pelajaran matematika dilaksanakan pada hari sabtu 24 Oktober 2020 pukul 09.00 sampai pukul 12.00 wib. bertempat di balai desa Pojok Kecamatan Campurdarat Kabupaten Tulungagung. Acara penyuluhan ini dihadiri oleh ibu-ibu wali murid kelas 2 dan kelas 3 yang putra putrinya bersekolah di SDN 3 Pojok, dimana lokasi sekolahnya tidak jauh dari kantor desa Pojok. Sebelum diadakan 
kegiatan penyuluhan pendampingan bagi orangtua, dilakukan pemberian angket kepada orangtua wali murid kelas 2 dan 3 SDN 3 Pojok, dimana isi angket berisi 10 pertanyaan uraian untuk dijawab oleh responden.

Tujuan dilakukan pemberian angket adalah untuk mengetahui kesulitan orang tua dalam mendampingi anak-anaknya belajar dirumah. Berdasarkan hasil angket diketahui bahwa kesulitan orangtua dalam mendampingi anak belajar adalah terdapat pada mata pelajaran Matematika dan Bahasa Inggris. Pada pelajaran Matematika materi yang dianggap sulit dalam mendampingi anak belajar khususnya kelas 2 dan 3 SD adalah pada materi perkalian dan pembagian bilangan.

Penyusunan materi penyuluhan berdasarkan pada permasalahan yang dialami oleh orangtua murid dalam mendampingi pembelajaran di rumah. Berdasarkan hasil angket yang diberikan kepada orang tua diperoleh hasil sebagai berikut:

Orang tua siswa sebagian besar tidak bisa mendampingi anak belajar di pagi hari karena bekerja disawah atau ladang. Kurangnya kesabaran orangtua dalam menghadapi anak ketika mendampingi belajar anak, waktu yang dihabiskan dirumah digunakan oleh siswa untuk bermain gadget dan bukan digunakan untuk lebih banyak belajar mata pelajaran sekolah, anak-anak bosan dengan pembelajaran daring yang dilaksanakan di rumah, dengan adanya pembelajaran dirumah, anak-anak tidak bisa bermain dengan teman-temannya. Masih kurangnya ketrampilan dan kemampuan dari orangtua dalam mendampingi belajar matematika dikarenakan belum pernah mendapat pendampingan sebelumnya. Berdasarkan hasil angket tersebut, maka tindaklanjut kami adalah memberikan materi penyuluhan berdasarkan beberapa permasalahan yang diperoleh dari hasil angket tersebut.

Pada saat acara penyuluhan dihadiri juga oleh beberapa perangkat desa yaitu Ibu Supangat, dan juga Ibu Kepala Desa yaitu ibu Ismiati dikarenakan Bapak kepala Desa (Bondan Wiratmoko, S.H) berhalangan hadir karena sedang sakit. Kegiatan penyuluhan ini dibantu oleh beberapa mahasiswa dari Program Studi Bahasa Inggris Universitas Bhinneka PGRI untuk membantu pelaksanaan secara teknis di lapangan. Acara penyuluhan dimulai pukul 09.00 diawali dengan sambutan Ibu Kepala Desa (Ibu Ismiyati). Tanggapan dari Ibu Kepala Desa sangat positif dan senang dengan adanya acara penyuluhan yang dilakukan. Ibu Kepala Desa selaku Ibu Penggerak PKK di Dusun Pojok mengharapkan supaya kegiatan ini dapat berlangsung lagi untuk kedepannya dan dapat ditindak lanjuti pasca adanya acara penyuluhan tersebut. Harapan ibu Ismiyati adalah para orangtua dapat mendampingi anaknya belajar dengan baik dan juga dapat memotivasi anak-anak dalam belajar matematika.

Setelah acara sambutan dari Ibu Kepala Desa yaitu masuk pada acara inti, dimana pada acara inti tersebut diisi oleh 3 Pemateri yaitu pemateri pertama diisi oleh Ibu. Dewi Anggreini. S.Si., M.Sc. Pemateri Kedua oleh Ibu Diesty Hayu Hantika, M.Pd. dan Pemateri Ketiga oleh Ibu Dr. Dra.Nanis Hairunisya, M.M. Pemateri satu menyampaikan materi tentang anggapan yang keliru terhadap matematika, perlunya belajar matematika, penerapan matematika dalam kehidupan sehari-hari disertai dengan contoh sederhana kegiatan matematika yang dilakukan dalam kehidupan seharihari. Penguatan materi tentang ruang dan bangun datar yaitu bagaimana menentukan sisi bangun datar, sisi bangun ruang, rusuk, diagonal dan Luas bangun.

Pemateri kedua memaparkan tentang materi penguatan perkalian dan pembagian menggunakan alat peraga yang mudah dijumpai dalam kehidupan sehari-hari. Pada materi kedua, orangtua siswa semakin memahami terhadap konsep menghitung perkalian dan pembagian dalam matematika sehingga lebih mudah menerapkan dan mengajari anak-anaknya ketika di rumah. Pemahaman orangtua terhadap matematika ternyata bukanlah hanya menghafal perkalian dan pembagian akan tetapi juga harus mengetahui konsep dasar bagaimana proses hasil perkalian dan pembagian. Pemateri ketiga berisi tentang metode-metode dalam pembelajaran yang terkait dengan karakter anak sekolah dasar. Setelah pemaparan dari ketiga narasumber tersebut, langkah selanjutnya adalah dilakukan sesi tanya jawab.

Setelah penjelasan materi, dilanjutkan dengan tanya jawab peserta kepada narasumber. Kegiatan dilanjutkan dengan sesi tanya jawab. Orang tua khususnya ibu-ibu yang paling berperan dalam perkembangan belajar anak banyak mengajukan pertanyaan. Respon positif dari para orang tua membuat narasumber bersemangat dalam menjawab pertanyaan. Beberapa peserta penyuluhan menceritakan pengalaman pribadinya dalam hal memberikan bimbingan 
belajar kepada anak. Peserta penyuluhan yang terdiri dari orangtua siswa menyambut dengan sangat antusias dengan adanya banyak pertanyaan dalam setiap materi yang diberikan. Pertanyaan yang ditanyakan oleh peserta langsung dijawab satu persatu oleh Pemateri, Ketika ada jawaban dari pemateri dirasa masih kurang, maka pemateri yang lain langung menambahi jawaban dari pertanyaan peserta. Interaksi yang terjadi pada acara penyuhan yaitu ketika pemateri menanyakan pertanyaan kepada anak didik peserta tentang permasalahan-permasalahan yang dialami anak didik dalam proses pembelajaran.
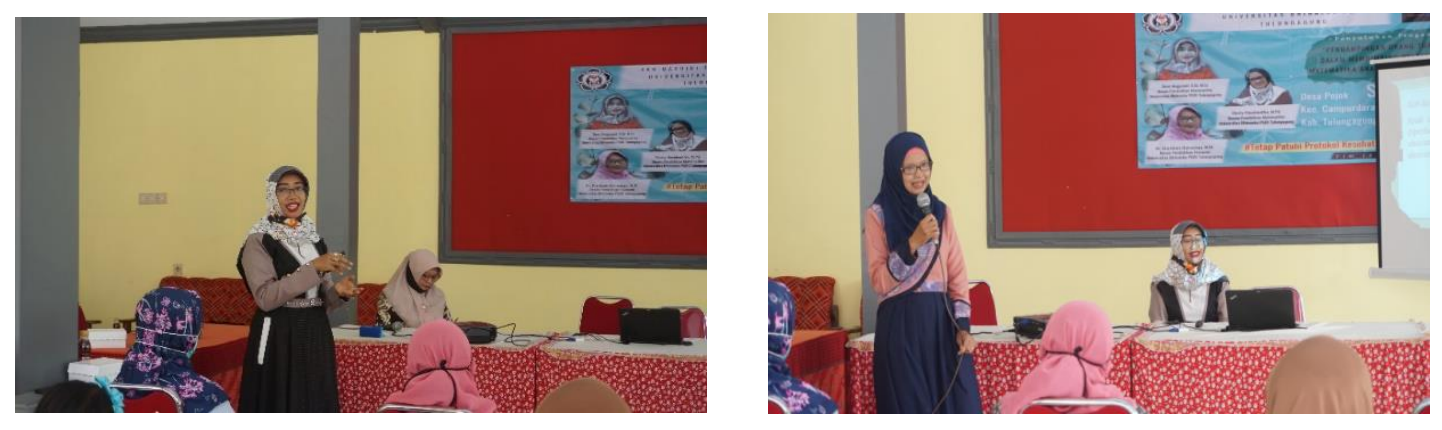

Fig. 2 (a)(b). Pembicara 1 dan 2 sedang melaksanakan penyuluhan kepada orang tua bagaimana mendampingi anak belajar matematika .
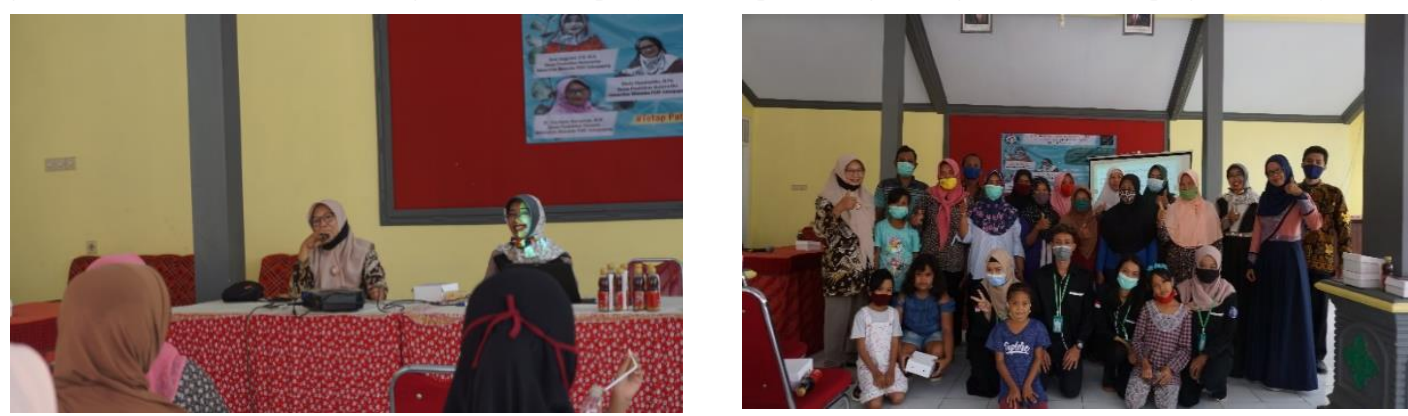

Fig. 3 (a)(b). Pembicara 3 sedang melaksanakan penyuluhan tentang metode mengajar yang tepat dan menyenangkan bagi anak \& sesi foto tim pengabdian bersama peserta di akhir acara penyuluhan

\subsection{Evaluasi Kegiatan}

Tahapan evaluasi dilakukan untuk mengetahui dampak kegiatan pendampingan pembelajaran ini terhadap anak anak tersebut dalam kemampuan matematika dasar dan motivasinya. Tahapan evaluasi ini dibedakan menjadi 2 jenis evaluasi, yaitu :

\subsubsection{Pengisian Kuesioner}

Pengisian Kuesioner dilakukan dengan bantuan salah seorang guru di SD Negeri 3 Pojok, yaitu diberikan kepada orang tua anak anak sekolah dasar kelas 2 dan 3. Orang tua siswa diminta untuk mengisi kuesioner yang telah dipersiapkan dengan terlebih dahulu diberi penjelasan bagaimana mengisi kuesioner tersebut. Pada kesempatan tersebut hadir 20 orang tua siswa yang diselenggarakan oleh pihak sekolah. Seluruh peserta mengisi kuesioner dengan lengkap. Hasil yang diperoleh adalah orangtua mendampingi anaknya ketika mereka belajar, akan tetapi dengan waktu yang bermacam-macam. Pada umumnya untuk tingkat Sekolah Dasar kelas 1 hingga kelas 3 harus selalu didampingi oleh orang tua mereka ketika melakukan pembelajaran dirumah. Usia untuk kelas tersebut masih belum bisa belajar mandiri. Setelah dilaksanakan pendampingan frekuensi orang tua dalam mendampingi anaknya belajar mengalami peningkatan. Berikut ini adalah diagram batang frekuensi pendampingan orang tua sebelum dan sesudah pendampingan ketika belajar matematika terhadap anak kelas 2 dan kelas 3. 


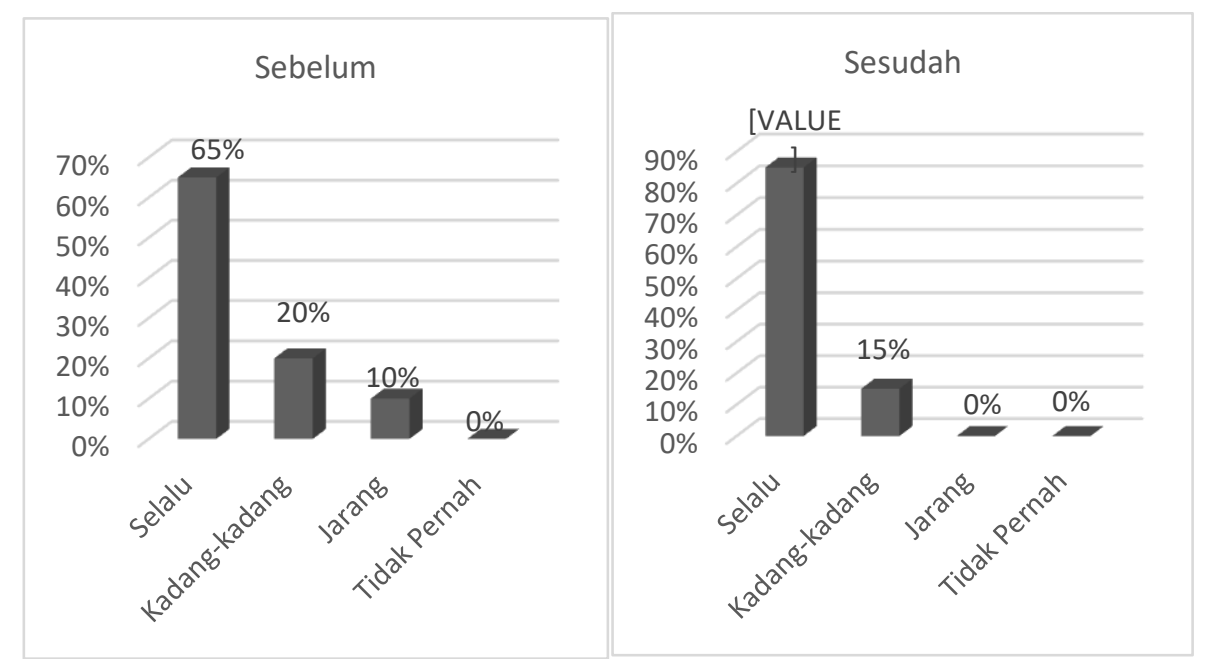

Fig. 4. Hasil Perhitungan Pendampingan Anak Ketika Belajar (Sebelum dan Sesudah)

\subsubsection{Wawancara}

Pada tahap wawancara, dilakukan terhadap anak didik peserta kegiatan pendampingan belajar serta kepada orang tua dari anak peserta. Wawancara kepada orangtua dilakukan pada awal dan pada akhir kegiatan penyuluhan. Pada awal kegiatan dilakukan, orangtua siswa memiliki banyak keluhan selama pembelajaran pada musim pandemic. Mereka banyak mengeluh dikarenakan anak-anak kurang diperhatikan akan pembelajaran sekolah disebabkan sibuknya para orangtua untuk bekerja sehingga orangtua tidak sepenuhnya mampu untuk mendampingi dalam proses belajar anak. Disamping itu sulitnya anak-anak untuk disuruh belajar setiap harinya, mereka lebih memilih untuk bermain diluar atau bermain gadget. Pada akhir acara kegiatan, orangtua mengaku bahwa banyak perubahan yang dirasakan oleh orangtua dengan adanya pembelajaran yang sudah diterapkan pada anak didik mereka. Terlebih juga anak-anak lebih semangat belajar matematika dikarenakan ada daya tarik dengan media pembelajaran yang baru dan menyenangkan.

Wawancara juga dilakukan kepada anak-anak peserta kegiatan penyuluhan. Pada awal kegiatan, anak-anak mengaku bahwa pelajaran yang paling susah adalah pelajaran matematika, menurut mereka matematika adalah pelajaran yang paling sulit. Anak-anak sebenarnya tidak mau mengikuti kegiatan penyuluhan tersebut dikarenakan anggapan anakanak bahwa pelajaran matematika adalah pelajaran yang sangat sulit. Mereka mau datang pada kegiatan penyuluhan pembelajaran tersebut jika diantar oleh orang tua mereka. Melalui beberapa pendekatan yang dilakukan oleh Tim pengabdian dengan cara memberikan pembelajaran matematika yang menyenangkan dengan menggunakan media pembelajaran yang menyenangkan dan teknik permainan dalam pembelajaran serta alat peraga yang mudah dijumpai disekitar mereka. Setelah akhir sesi acara, anak-anak terlihat lebih semangat dan antusias dalam menerima pembelajaran khususnya pembelajaran matematika.

Beberapa hasil dari kegiatan Pendampingan Belajar Matematika di Desa Pojok Kecamatan Campurdarat adalah sebagai berikut: Dari hasil wawancara, setelah dilakukan penyuluhan dan pendampingan kepada orang tua. Peserta penyuluhan menjadi semakin percaya diri dalam mendampingi putra-putrinya dalam pembelajaran matematika. Banyak dari ibu-ibu yang mengaku bahwa dengan adanya penyuluhan dan pendampingan ini mereka semakin antusias dalam mendampingi putra-putrinya untuk belajar matematika selama pembelajaran dirumah. Para Ibu semakin percaya diri dengan penguasaan materi yang diperoleh serta sudah mengetahui cara-cara mendampingi anak dalam belajar. Keterlibatan orang tua dalam kegiatan belajar putera-puterinya belajar di rumah meningkat, tercermin dari pengakuan orang tua mengenai peningkatan frekuensi orang tua dalam mendampingi putera-puteri mereka belajar matematika di rumah. Bagi dosen pengajar, mampu mengidentifikasi dan mencari solusi untuk turut 
berperan aktif menyelesaikan persoalan di masyarakat. Bagi mahasiswa tutor pengajar, mereka mengakui mereka menjadi mampu menerapkan pengetahuannya untuk turut berperan aktif memberdayakan masyarakat dan mengembangkan semangat bela rasa dan kepedulian kepada sesama.

\section{Kesimpulan dan Saran}

\subsection{Kesimpulan}

Berdasarkan uraian sebelumnya dan dari hasil pelaksanaan kegiatan pengabdian kepada masyarakat, dapat diambil kesimpulan sebagai berikut:

Perlunya kesadaran dari orangtua akan pentingnya mendampingi belajar anak dirumah, khususnya belajar matematika. Pada dasarnya siswa dapat nyaman belajar matematika apabila hatinya merasakan senang dengan matematika. Berdasarkan hasil evaluasi berupa angket terlihat bahwa orang tua sangat antusias dan pengetahuannya bertambah setelah mengikuti pelatihan ini. Berdasarkan wawancara langsung tentang kegiatan ini dengan para orang tua siswa, semua peserta merasa senang karena bisa lebih sering mendampingi dan membatu putra putrinya belajar dirumah setelah pelatihan yang didapat. Berdasarkan evaluasi program yang dilaksanakan, program yang dirancang ternyata sudah sesuai dengan tujuan yang ingin dicapai. Para orang tua hendaknya memberikan pengetahuan matematika sejak dini bagi anak khususnya untuk anak kelas awal yaitu kelas 1, 2, dan 3. Dengan pengetahuan matematika dasar orang tua mendapatkan bekal keterampilan dalam mendampingi anak-anaknya belajar matematika. Orang tua bisa menggunakan alat peraga matematika dalam membimbing putra putrinya belajar matematika. Anakanak sangat memerlukan alat peraga untuk membantu agar siswa mampu memahami konsep-konsep matematika, terutama sekali siswa di kelas-kelas rendah ( kelas 1, 2 dan 3) karena pada usia ini anak akan lebih memahami konsep-konsep matematika yang abstrak. Dengan alat peraga benda-benda konkrit yang ada di lingkungan sekitar siswa lebih mudah belajar matematika tentang penjumlahan, perkalian dan pembagian.

\subsection{Saran}

Orang tua harus sabar dan konsisten dalam mendampingi anak-anak belajar matematika dikarenakan untuk anak usia sekolah dasar khususnya kelas awal masih membutuhkan dukungan ekstra dari orang tuanya dalam belajar. Dalam mendampingi anak belajar matematika orang tua siswa dapat menggunakan alat peraga karena dapat membantu anakanak untuk lebih mudah belajar matematika. Agar matematika lebih mudah diterima anak dan minat anak meningkat terhadap matematika maka perlu mengaplikasikan matematika dalam kehidupan sehari-hari. Selain itu orang tua perlu menerapkan metode yang tepat untuk mengajarkan matematika khususnya untuk anak-anak kelas awal seperti dengan permainan agar matematika menjadi lebih mudah dan menyenangkan. Berdasarkan hasil pelaksanaan kegiatan yang telah dilakukan maka dapat disarankan perlu adanya kegiatan pelatihan untuk orang tua siswa ini berkelanjutan dengan materi yang lain yang terkait matematika.

\section{References}

Abidin, Z. (2020) Belajar Matematika di Era COVID 19. Available at: https://www.researchgate.net/publication/341423253 (accessed: 4 September 2020).

Agustin, D. S. Y., Sumarmini, N. W. and Prabowo, S. (2015) 'Peran Keluarga Sangat Penting dalam Pendidikan Mental, Karakter Anak serta Budi Pekerti Anak’, Jurnal Sosial Humaniora, 8(1), pp. 46-54.

BPS. (2020). Profil Desa Pojok Kecamatan Campurdarat, Badan Pusat Statistik Kabupaten Tulungagung. Available at: https://tulungagungkab.bps.go.id (accessed: 20 September 2020).

Hasbullah. (2005). Dasar - Dasar Ilmu Pendidikan. Jakarta: Raja Grafindo. 
Hulukati, W. (2015). Peran Lingkungan Keluarga terhadap Perkembangan Anak.MUSAWA, 7(2).265-282

Kemendikbud (2020) Daftar Satuan Pendidikan Sekolah Kec. Tulungagung. Available at: https://referensi.data.kemdikbud.go.id/index11.php (accessed: 20 September 2020).

Purwanto, S. . and Kurniasih, M. D. (2018) 'Pendampingan Orang Tua Membimbing Matematika Anak di Jatiluhur, Jatiasih, Kota Bekasi’, Jurnal SOLMA, 7(1), pp. 120-126.

Saputro. (2018). Memasyarakatkan Matematika Melalui Peran Keluarga. Jurnal Transformasi. 14(2), pp. 44-54.

Subianto, J. (2013). Peran Keluarga, Sekolah dan Masyarakat dalam Pembentukan Karakter yang Berkualitas. Jurnal Penelitian Pendidikan Islam, 8(2), pp. 331-354. 